\title{
PENGGUNAAN MEDIA PEMBELAJARAN ADOBE FLASH CS 6 UNTUK MENINGKATKAN MINAT DAN HASIL BELAJAR SISWA PADA KOMPETENSI DASAR MENDESKRIPSIKAN SISTEM PEMBAYARAN DAN ALAT PEMBAYARAN
}

(Studi Kasus Pada Kelas X IPS 4 MAN 1 Jember Semester Genap Tahun Ajaran 2017/2018)

\author{
Ali Ahmad Farhan', Titin Kartini' ${ }^{1}$, Sri Kantun ${ }^{1}$ \\ ${ }^{1}$ Program Studi Pendidikan Ekonomi, Fakultas Keguruan dan Ilmu Pendidikan, Universitas Jember \\ e-mail: Ali.ahmad.farhan@gmail.com
}

\begin{abstract}
Abstrak
Penelitian ini bertujuan untuk mengetahui peningkatan minat dan hasil belajar siswa kelas X IPS 4 MAN 1 Jember menggunakan media pembelajaran Adobe Flash CS6 untuk meningkatkan minat dan hasil belajar siswa pada kompetensi dasar mendeskripsikan sistem pembayaran dan alat pembayaran (studi kasus pada kelas X IPS 4 MAN 1 Jember semester genap tahun ajaran 2017/2018). Penelitian ini merupakan penelitian tindakan kelas yang dilaksanakan dengan 2 siklus yang terdiri dari beberapa tahapan yaitu, perencanaan, pelaksanaan tindakan, observasi, dan refleksi. Metode pengumpulan data yang digunakan adalah observasi, tes, wawancara, dan dokumen. Penelitian ini menggunakan analisis data secara deskriptif dengan pendekatan kualitatif yaitu memaparkan data yang diperoleh peneliti dari hasil pelaksanaan tindakan. Hasil penelitian ini menunjukkan bahwa penggunaan media pembelajaran dengan aplikasi Adobe Flash CS6 dapat meningkatkan minat dan hasil belajar pada kompetensi sistem pembayaran dan alat pembayaran siswa kelas X IPS 4 MAN 1 Jember Semester Gasal Tahun Pelajaran 2017/2018. Pada siklus I minat belajar siswa dalam kategori sedang dengan skor 2,9, pada siklus II meningkat menjadi kategori tinggi dengan skor 3,4. Sedangkan, rata-rata ketuntasan hasil belajar siswa pada siklus I sebesar 79 dengan ketuntasan belajar siswa secara klasikal 74\%. Pada siklus II mengalami peningkatan ketuntasan belajar siswa sebesar 81,42 dengan ketuntasan belajar siswa secara klasikal sebesar $85,18 \%$.
\end{abstract}

Kata Kunci: Adobe Flash C6, Minat Belajar, Hasil Belajar

\section{PENDAHULUAN}

Pembelajaran merupakan kegiatan interaksi antara guru dengan siswa dan timbal balik yang berlangsung pada saat proses pembelajaran untuk mencapai tujuan belajar. Tujuan pembelajaran adalah diperolehnya hasil belajar siswa yang sesuai standar dan terdapat perubahan perilaku positif pada siswa. Oleh karena itu perlu dilakukan proses pembelajaran yang berkualitas yang ditunjang oleh penerapan beberapa unsur-unsur pembelajaran. Unsur-unsur pembelajaran tersebut antara lain, tujuan belajar belajar yang dirumuskan dengan jelas, materi pelajaran yang disusun secara runtut, sarana prasarana belajar memadai, kondisi belajar nyaman, penggunaan metode pembelajaran yang tepat, penggunaan media pembelajaran yang mampu mendukung proses pembelajaran.

Proses pembelajaran ekonomi yang selama ini berlangsung di MAN 1 Jember masih bergantung dengan media power point, media yang masih monoton dan tidak menarik siswa untuk belajar. Hal tersebut berdampak pada rendahnya minat belajar dan hasil belajar siswa terhadap materi yang dipelajari. Oleh karena itu, guru harus variatif dalam memilih media pembelajaran yang sesuai dengan karakteristik mata pelajaran ekonomi khususnya pada kompetensi dasar sistem pembayaran dan alat pembayaran.

Berdasarkan informasi guru pada observasi pendahuluan dikelas, selama proses pembelajaran berlangsung terlihat siswa kelas X IPS 4 memiliki minat belajar paling rendah terhadap materi pelajaran ekonomi

Jumlah skor rata-rata minat belajar siswa kelas XI IPS pada mata pelajaran ekonomi

\begin{tabular}{|c|c|}
\hline Kelas & Jumlah Siswa \\
\hline
\end{tabular}


Jurnal Pendidikan Ekonomi: Jurnal Ilmiah Ilmu Pendidikan, Ilmu Ekonomi, dan Ilmu Sosial

ISSN 1907-9990 | E-ISSN 2548-7175 | Volume 12 Nomor 2 (2018)

DOI: 10.19184/jpe.v12i2.8559

\begin{tabular}{llll}
\hline XI IPS 1 & 35 & 2,00 & Sedang \\
\hline XI IPS 2 & 38 & 2,00 & Sedang \\
\hline XI IPS 3 & 37 & 1,41 & Rendah \\
\hline XI IPS 4 & 27 & 1,26 & Rendah
\end{tabular}

Sumber : Data primer yang diolah 2017.

Hal tersebut ditunjukkan dengan tabel observasi pendahuluan siswa kelas tersebut memiliki skor 1,26 yang menunjukkan siswa kelas X IPS 4 kurang memiliki rasa senang terhadap materi pelajaran ekonomi. sehingga siswa banyak yang meninggalkan kelas dengan bermacam-macam alasan, kurangnya perhatian siswa dalam proses pembelajaran masih banyak siswa yang bermain dan berbicara sendiri selama proses pembelajaran, kurangnya keaktifan siswa selama proses pembelajaran, dan kurangnya ketertarikan siswa terhadap materi pelajaran ekonomi. Permasalahan ini sering terjadi di setiap pembelajaran mata pelajaran ekonomi dan mengganggu proses pembelajaran dalam kelas.

Minat belajar siswa yang rendah berdampak pada hasil belajar yang rendah. Berdasarkan dokumen yang diperoleh dari guru ekonomi bahwa daftar nilai untuk kelas X IPS MAN 1 Jember diketahui hasil belajar siswa kelas X IPS yang diperoleh ulangan harian pada kompetensi dasar mendeskripsikan konsep pembangunan ekonomi, pertumbuhan ekonomi, permasalahan dan cara mengatasinya .

Berdasarkan informasi dari guru bahwa kelas XIPS 4 memiliki nilai rata-rata yang paling rendah dibandingkan dengan kelas X IPS 1, X IPS 2, X IPS 3. Hal tersebut ditunjukkan dengan nilai rata-rata kelas XIPS 4 sebesar 68,5 dengan ketuntasan klasikal siswa sebesar 55,3\% lebih rendah dibandingkan kelas lain yang memiliki nilai rata-rata diatas 75. Adapun Kriteria Ketuntasan Minimal di MAN 1 Jember yaitu 75. Berdasarkan hasil nilai ulangan mata pelajaran ekonomi diatas, hasil belajar siswa kelas X IPS secara klasikal belum semuanya tuntas baik kelas X IPS 1, X IPS 2, X IPS 3, dan XIPS 4. Hal tersebut ditunjukkan oleh presentase ketuntasan klasikal kelas X IPS masih dibawah 75\%, tetapi kelas XIPS 4 memiliki presentase ketuntasan hasil belajar yang paling rendah dibandingkan yang lain.

Berdasarkan permasalahan yang terjadi dikelas X IPS 4 MAN 1 Jember yaitu rendahnya minat dan hasil belajar siswa pada mata pelajaran ekonomi, maka perlu ditingkatkan untuk mencapai Ketuntasan Kriteria Minimum (KKM) yang telah ditetapkan sekolah. Menurut siswa di kelas X IPS 4 selama ini proses pembelajaran pada mata pelajaran ekonomi menggunakan media power point.rendahnya minat dan hasil belajar siswa disebabkan karena media yang digunakan guru kurang menarik bagi siswa sehingga siswa merasa cepat bosan terhadap kegiatan pembelajaran dikelas. Oleh karena itu guru memerlukan inovasi dengan memanfaatkan media pembelajaran. Inovasi media pembelajaran untuk meningkatkan minat dan hasil belajar siswa adalah menerapkan media pembelajaran Adobe Flash Cs6.Penerapan pembelajaran dengan Adobe Flash Cs6yang memberikan animasi-animasi yang bagus akan lebih menarik bagi siswa karena memberikan minat belajar dalam proses pembelajaran dibandingkan dengan pembelajaran dikelas seperti biasanya sehingga siswa memiliki minat belajar yang lebih tinggi. Oleh karena itu, pada waktu tertentu guru perlu menerapkan sebuah media pembelajaran yang variatif supaya siswa tidak bosan dan memiliki minat belajar yang tinggi sehingga dapat meningkatkan hasil belajar siswa.

Adobe Flash Cs6software yang memiliki kemampuan menggambar sekaligus animasi, serta mudah dipelajari menurut Akbar, dkk (2008). Flash tidak hanya digunakan dalam pembuatan animasi, tetapi pada zaman sekarang ini flash juga banyak digunakan untuk keperluan lainnya seperti dalam pembuatan game, presentasi, membangun web, animasi pembelajaran, bahkan juga dalam pembuatan film. Animasi yang dihasilkan flash adalah animasi berupa file movie. Movie yang dihasilkan dapat berupa grafik atau teks. Grafik yang dimaksud disini adalah grafik yang berbasis vektor, sehingga saat diakses melalui internet, animasi akan ditampilkan lebih cepat dan terlihat halus. Selain itu flash juga memiliki kemampuan untuk mengimpor file suara, video maupun file gambar dari aplikasilain.

Berdasarkan permasalahan diatas maka penulis bermaksud untuk melakukan penelitian mengenai masalah tersebut, maka penulis menuliskan judul "Penggunaan Media Pembelajaran Adobe Flash CS6 Untuk Meningkatkan Minat Dan Hasil Belajar Siswa Pada Kompetensi Dasar Mendeskripsikan Sistem Pembayaran dan Alat Pembayaran(Studi Kasus Pada Kelas X IPS 4 MAN 1 Jember Semester Genap Tahun Ajaran 2017/2018)". 


\section{METODE}

Penelitian ini merupakan penelitian tindakan kelas yang dilaksanakan dengan 2 siklus yang terdiri dari beberapa tahapan yaitu perencanaan, pelaksanaan, pengamatan dan refleksi. Metode pengumpulan data yang digunakan yaitu observasi, wawancara dan dokumentasi. Penelitian ini menggunakan analisis data deskriptif dengan pendekatan kualitatif yaitu memaparkan data yang diperoleh dari hasil pelaksanaan tindakan. Subyek penelitian ini seluruh siswa kelas X IPS 4 MAN 1 Jember yang berjumlah 27 siswa terdiri dari 14 siswa lakilaki dan 13 siswi perempuan

\section{HASIL DAN PEMBAHASAN}

\section{Hasil Penelitian}

Hasil observasi selama proses pembelajaran pada siklus I menunjukkan minat belajar siswa masih dalam kategori sedang. Hal tersebut dikarenakan pada proses pembelajaran pada siklus I siswa masih belum terbiasa dengan penggunaan media pembelajaran Adobe Flash CS6. Media pembelajaran Adobe Flash CS6 merupakan media pembelajaran yang baru bagi siswa, sehingga siswa mengalami kesulitan dalam mengikuti proses pembelajaran dengan media tersebut. Kekurangan yang terjadi pada siklus I dilakukan perbaikan pada siklus II dan hasilnya terjadi peningkatan pada minat belajar siswa yang meningkat dari sedang menjadi tinggi.

Peningkatan minat belajar siswa dari siklus I pada siklus II dapat dilihat pada tabel berikut :

Tabel 3 Peningkatan Minat Belajar Siswa Siklus 1 Pada Siklus II

\begin{tabular}{ccc}
\hline Siklus & Skor rata-rata minat belajar siswa & Kategori \\
\hline Sikus I & 2,91 & Sedang \\
Siklus II & 3,4 & Tinggi \\
\hline
\end{tabular}

Sumber : Data Primer yang diolah

Dari tabel diatas dapat dilihat bahwa terjadi peningkatan pada minat belajar siswa dari siklus I sebesar 2,91 dengan kategori sedang, meningkat pada siklus II menjadi 3,4 dengan kategori aktif. Peningkatan paling tinggi terjadi pada indikator perasaan senang siswa terhadap mata pelajaran dan skor terendah pada indikator keterlibatan siswa selama proses pembelajaran. Hal tersebut karena siswa sudah mulai terampil dan terbiasa dalam menggunakan media Adobe Flash CS6 sebagai media pembelajaran, sehingga siswa semangat dan antusias dalam mengikuti proses pembelajaran yang ditunjukkan dengan siswa mulai aktif ketiga guru memberikan stimulus, siswa mulai bersemangat dalam mengerjakan tugasnya, serta siswa ikut perperan aktif dalam diskusi kelompoknya.

Peningkatan minat belajar siswa juga dapat dilihat pada grafik berikut :

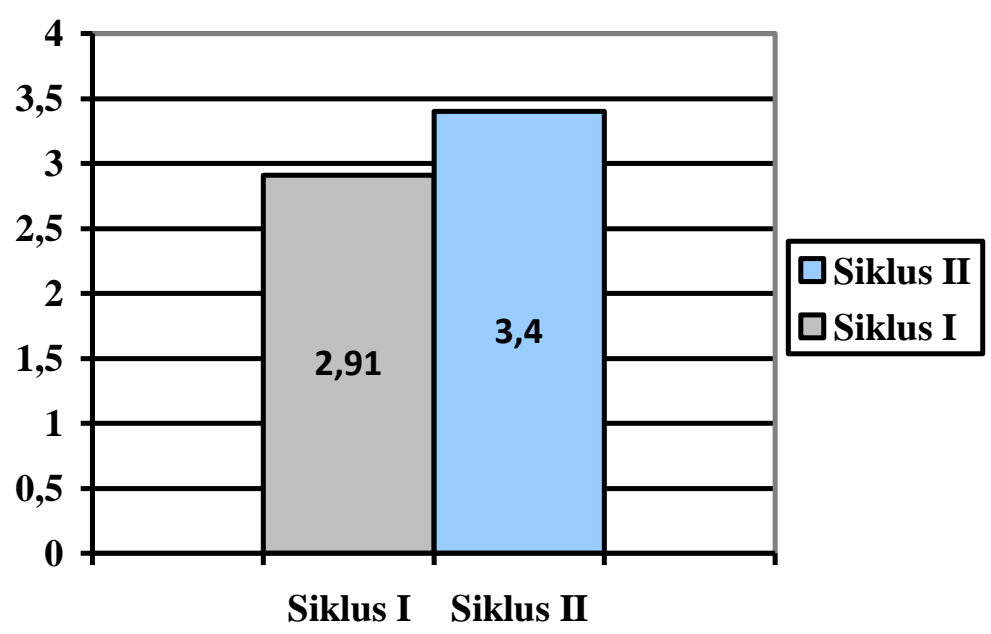


Gambar 1 Peningkatan Minat Belajar Siswa Siklus I pada Siklus II

Berdasarkan tabel dan gambar diatas menunjukkan bahwa minat belajar siswa terjadi peningkatan dari siklus I ke siklus II. Pada siklus I skor minat belajar siswa sebesar 2,91 sedangkan pada siklus II mengalami peningkatan menjadi 3,4.

Peningkatan minat belajar siswa juga sejalan dengan peningkatan hasil belajar siswa. Peningkatan hasil belajar siswa dari siklus I ke siklus II dapat dilihat pada tabel berikut :

Tabel 4 Peningkatan Hasil Belajar Siswa kelas X IPS 4 Siklus I pada Siklus II

\begin{tabular}{cccc}
\hline Siklus & Jumlah siswa & Nilai rata-rata & Ketuntasan klasikal siswa \\
\hline I & 27 & 79 & $74 \%$ \\
\hline II & 27 & 81,42 & $85,18 \%$ \\
\hline
\end{tabular}

Sumber : Data primer yang diolah

Pada tabel diatas dapat dilihat bahwa terjadi peningkatan pada hasil belajar siswa. Peningkatan nilai ratarata siswa yakni dari 79 meningkat menjadi 81,42, terjadi peningkatan sebesar 2,42. Sedangkan peningkatan ketuntasan klasikal dari siklus I ke siklus 2 dapat dilihat dalam grafik berikut :

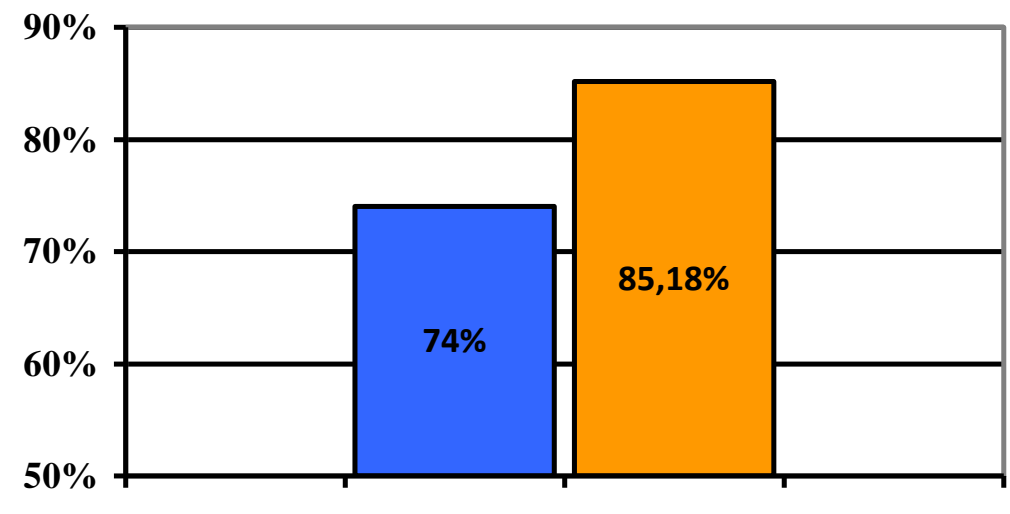

Siklus I Siklus II

Gambar 2 Peningkatan Ketuntasan Klasikal Hasil Belajar Siswa Siklus I dan Siklus II

Berdasarkan gambar diatas dapat dilihat bahwa ketuntasan belajar siswa secara klasikal mengalami peningkatan dari siklus I ke siklus II. Peningkatan tersebut terlihat dari siklus I sebesar 74\% dan siklus II sebesar $85,18 \%$, terjadi peningkatan sebesar $8,82 \%$.

\section{Pembahasan}

Berdasarkan penelitian yang telah dilaksanakan di kelas X IPS 4 MAN 1 Jember bahwa pelaksanaan penggunaan media pembelajaran Adobe Flash CS6 berjalan lancar dan sesuai dengan rencana yang telah disusun pada tahap perencanaan. Meskipun pada siklus I terdapat beberapa kendala karena siswa masih belum terbiasa dengan penggunaan media Adobe Flash CS6, sehingga kelas menjadi kurang kondusif. Siswa juga masih sulit menerima pelajaran yang diberikan oleh guru. namun setelah tindakan perbaikan dilakukan pada siklus II, siswa mulai terbiasa dalam penggunaan media pembelajaran Adobe Flash CS6 dan siswa juga mulai merespon stimulus yang diberikan oleh guru yang ditunjukkan siswa mulai berani bertanya dan menjawa pertanyaan yang diberikan oleh guru.

Hasil penelitian pada siklus I menunjukkan bahwa penggunaan media pembelajaran Adobe Flash CS6 dapat meningkatkan minat dan hasil belajar siswa pada mata pelajaran strategi pemasaran kompetensi dasar Sistem pembayaran dan alat pembayaran kelas X IPS 4 MAN 1 Jember tahun ajaran 2017/2018. Minat belajar siswa yang diobservasi dalam penelitian ini meliputi perasaan senang siswa terhadap mata pelajaran, keterlibatan siswa selama proses pembelajaran, ketertarikan siswa terhadap mata pelajaran, dan perhatian siswa selama proses pembelajaran. hasil observasi minat belajar siswa mengalami peningkatan dari sedang menjadi tinggi. Peningkatan minat belajar ini nampak dari rata-rata skor indikator minat belajar siswa yaitu sebesar 2,91 
pada siklus I dengan kriteria sedang, dari sebelum dilaksanakan tindakan skor rata-rata minat belajar siswa hanya 1,26 dengan kriteria rendah. Hasil belajar siswa juga meningkat sesuai dengan target penelitian yaitu siswa mencapai KKM yang ditetapkan sekolah yaitu $\geq 75$, hal tersebut ditunjukkan dengan nilai rata-rata siswa mencapai 79 pada siklus I dengan ketuntasan klasikal sebesar 74\%. Hal ini membuktikan bahwa hipotesis yang diajukan dalam penelitian ini terbukti.

Hasil penelitian pada siklus II menunjukkan bahwa penggunaan media pembelajaran Adobe Flash CS6 dapat meningkatkan minat dan hasil belajar siswa. Hal tersebut nampak pada peningkatan skor rata-rata minat belajar dari siklus I yang semula hanya 2,91 dengan kriteria sedang, meningkat pada siklus II dengan skor ratarata 3,4 dengan kriteria tinggi. Selain terjadi peningkatan minat belajar siswa, hasil belajar siswapun ikut mengalami peningkatan. Pada siklus I nilai rata-rata siswa adalah 79 dengan ketuntasan klasikal sebesar $74 \%$, meningkat pada siklus II niali rata-rata siswa menjadi 81,42 dengan ketuntasan klasikal menjadi 85,18\%.

Peningkatan minat belajar siswa dapat dilihat pada saat proses pembelajaran dengan menggunakan media pembelajaran Adobe Flash CS6, siswa sangat antusias mengikuti proses pembelajaran dengan mendengarkan dan memperhatikan video yang diberikan guru melalui media Adobe Flash CS6, siswa segera mengerjakan tugas yang diberikan oleh guru. selain itu, siswa juga aktif merespon pelajaran yang diberikan oleh guru yang ditunjukkan dengan siswa berani bertanya dan menjawab pertanyaan yang diberikan oleh guru.

Minat belajar siswa dari siklus I hingga siklus II mengalami peningkatan, pada siklus I skor minat belajar siswa mencapai 2,91 dengan kriteria sedang, kemudian pada siklus II meningkat menjadi 3,4 dengan kriteria tinggi. Peningkatan minat belajar siswa ini dikarenakan peneliti dan guru merancang perbaikan dari kekurangankekurangan pada siklus I yang kemudian dilaksanakan pada siklus II untuk meningkatkan minat belajar siswa, sehingga masing-masing skor indikator minat belajar siswa pada siklus I berada pada kriteria sedang, meningkat menjadi kriteria tinggi pada siklus II. Siklus II menunjukkan skor minat belajar siswa sudah mencapai target penelitian. Peningkatan minat belajar tersebut didukung oleh teori yang diungkap Arsyad (2016:29) menyatakan bahwa media pembelajaran dapat meningkatkan dan mengarahkan perhatian siswa sehingga dapat menimbulkan minat belajar.

Setiap pertemuan akhir pada masing-masing siklus diadakan ulangan harian. Siklus I nilai rata-rata siswa mencapai 79 dengan ketuntasan klasikal sebesar 74\%. Hasil belajar siklus I tersebut sudah mengalami peningkatan karena sebelum tindakan nilai rata-rata siswa sebesar 68,5 dengan ketuntasan klasikal 55,33\% dan peningkatan pada siklus I mencapai target penelitian, dan secara klasikal sudah tuntas. Ketuntasan hasil belajar siswa pada siklus I karena materi disajikan dengan media yang berbeda dari biasanya yaitu dengan menggunakan media pembelajaran Adobe Flash CS6 dalam suatu ruangan pembelajaran yang lebih menarik dan menyenangkan, sehingga siswa lebih tertarik dan merasa senang dalam mengikuti proses pembelajaran. Kondisi yang demikian membuat siswa lebih mudah memahami materi yang diberikan oleh guru dalam proses pembelajaran.

Penggunaan media pembelajaran Adobe Flash CS6 pada siklus II berjalan secara optimal. Pada siklus II pertemuan kedua dilakukan ulangan harian yang kedua kalinya, pada tes yang kedua ini didapat nilai rata-rata siswa mencapai 81,42 dengan ketuntasan klasikal sebesar 85,18\%. Sehingga dapat dikatakan hasil tes ulangan harian pada siklus II dinyatakan tuntas dan telah mencapai target penelitian. Peningkatan hasil belajar diatas didukung oleh teori Arsyad (2016:29) menyatakan bahwa media pembelajaran dapat memperjelas penyajian pesan dan informasi sehingga dapat memperlancar proses belajar dan meningkatkan hasil belajar.

Peningkatan minat belajar dan hasil belajar siswa juga diakui oleh guru mata pelajaran ekonomi kelas X IPS 4 MAN 1 Jember selaku pelaksana dari kegiatan perbaikan pembelajaran. Hal tersebut ditunjukkan oleh hasil wawancara dengan guru yang menyatakan:

“...minat belajar siswa cukup terlihat bahwa ada peningkatan saat siswa mengikuti pembelajaran didalam kelas menggunakan media Adobe Flash CS6 ini. Siswa sudah mulai berani bertanya baik kepada guru maupun kepada teman saat dilakukan diskusi. Selain itu siswa sangat bersemangat setiap saat guru memberikan tugas dalam media Adobe Flash CS6 tersebut. ”(Nely S, 40 Tahun).

Berdasarkan pernyataan guru diatas menunjukkan bahwa penggunaan media pembelajaran Adobe Flash CS6 dapat meningkatkan minat belajar siswa. Adobe Flash CS6 mampu merangsang siswa untuk bertanya dan 
aktif selama proses pembelajaran berlangsung dengan begitu pada penggunaan media ini dapat meningkatkan minat belajar siswa dari sebelumnya.

Peningkatan minat dan hasil belajar siswa juga dirasakan oleh siswa berdasarkan hasil wawancara kepada siswa yang memiliki hasil belajar tertinggi, yaitu:

“...saya bersemangat ketika guru menggunakan media Adobe Flash CS6 sebagai media pembelajaran di kelas saya. Karena media ini merupakan media yang baru bagi saya dan saya bisa mempelajarinya kembali saat dirumah hanya dengan membuka media Adobe Flash CS6 ini kak. Jadi ini mempermudah saya dalam belajar." (Yunita, 16 Tahun)

Pernyataan siswa tersebut sesuai dengan pendapat Rusman (2014:351) mengemukakan bahwa salah satu kelebihan media Adobe Flash CS6 ini adalah siswa dapat belajar atau me-review bahan ajar atau materi setiap saat dan dimana saja ketika diperlukan. Selain itu, siswa juga dapat bertanya kepada guru ataupun kepada siswa lain menggunakan media Adobe Flash CS6 ini pada saat diluar jam pelajaran, sehingga dengan kondisi yang demikian siswa lebih meyakini bahwa materi yang dipelajarinya benar sehingga hasil belajar siswa juga akan baik. Dengan demikian dapat dikatakan bahwa penggunaan media Adobe Flash CS6 dapat meningkatkan minat dan hasil belajar siswa.

Berdasarkan hasil penelitian tindakan ini membuktikan bahwa hasil penelitian ini telah menjawab hipotesis tindakan yaitu penggunaan media pembelajaran Adobe Flash CS6 dapat meningkatkan minat dan hasil belajar siswa kelas X IPS 4 MAN 1 Jember pada kompetensi dasar mendeskripsikan sistem pembayaran dan alat pembayaran semester genap tahun ajaran 2017/2018. Akhirnya, dengan tercapainya tujuan penelitian dan terbuktinya hipotesis tindakan, maka penelitian ini dinyatakan berhasil.

\section{PENUTUP}

Berdasarkan hasil penelitian dan pembahasan pada bab sebelumnya maka dapat ditarik kesimpulan sebagai berikut:Penggunaan media pembelajaran Adobe Flash CS6 pada pelajaran ekonomi materi system pembayaran dan alat pembayaran kelas X IPS 4 MAN 1 Jember tahun ajaran 2017-2018 dapat meningkatkan minat belajar dan hasil belajar siswa. Peningkatan minat belajar berupa perasaan senang siswa terhadap mata pelajaran, keterlibatan siswa selama proses pembelajaran, ketertarikan siswa terhadap mata pelajaran. Peningkatan minat belajar diiringi dengan peningkatan hasil belajar, hal ini disebabkan karena media Adobe Flash CS6 sangat bagus dan siswa sangat suka dalam belajar dan memudahkan guru untuk memahamkan siswa dalam kegiatan pembelajaran di dalam kelas.

Penggunaan media pembelajaran Adobe Flash CS6 dapat meningkatkan minat belajar siswa. Minat belajar siswa sebelum tindakan sebesar 1,26 masuk pada kategori "rendah", setelah pelaksanaan siklus 1 minat belajar siswa meningkat menjadi 2,91 masuk pada kategori "sedang" dan pada siklus 2 meningkat kembali menjadi 3,4 masuk pada kategori “tinggi”.Penggunaan media Adobe Flash CS6 dapat meningkatkan hasil belajar siswa. Hal ini dibuktikan dengan presentase siswa yang mendapat nilai di atas KKM pada sebelum tindakan sebesar 55,3\%, setelah pelaksanaan siklus 1 meningkat menjadi $74 \%$ dan pada siklus 2 meningkat kembali menjadi $85,18 \%$.

\section{DAFTAR PUSTAKA}

Arsyad,A. 2002. Media Pembelajaran, Jakarta: Rajawali Pers

Daryanto.2011.Media Pembelajaran. Bandung: Satu Nusa Studio

Madcoms. 2012. Adobe Dreammweaver CS6 dan PHP-MYSQL untuk Pemula. Yogyakarta: Andi

Slameto. 2010. Belajar dan Faktor-faktor yang Mempengaruhinya. Jakarta: Rineka Cipta.

Suprijono, A. 2015. Cooperatuve Learning (Teori dan Aplikasi Paikem). Yogyakarta: Pustaka Pelajar 